\title{
NEW RELIGIOUS MOVEMENTS AND THE STUDY OF FOLKLORE: THE RUSSIAN CASE
}

\section{Alexander Panchenko}

\begin{abstract}
The present article deals with the question of emergence of new religious movements in contemporary Russia. Although sociological approach to the study of new religious movements proceeds usually from the theories of secularization, the author claims that the appearance of these movements should be viewed also in various contexts of national and historical peculiarities of different cultures. He stresses the importance of new urban mythology and semi-Orthodox mysticism as a basis for autochthonous Russian new religious movements emerged in the 1990s. The collapse of the Soviet ideology evidently resulted in the symbolic vacuum, which was to be filled with diverse social, political, religious and ideological patterns. Proceeding from the study of religious practices and personal narratives by the followers of "The Last Testament Church" (also known as "the sect of Vissarionovtsy"), the author argues that indigenous Russian new religious movements appear to be typical "crisis cults" comparable to so-called "cargo-cults" and other messianic and prophetic movements of this kind. This particular case demonstrates that the rise and functioning of new religious movements are often more complicated and probably depend not only on the secularization.
\end{abstract}

Keywords: Contemporary folklore, new religious movements, popular religion in Russia

During the second half of the twentieth century, new religious movements or "cults" were the issue of continuing debates both in the USA and Western Europe. The discussion has been highly stimulated by the Jonestown and the Waco massacres, the Solar Temple suicide and other tragic events related to the apocalyptic beliefs being widespread amongst new religious movements (Hall \& Schuyler $\&$ Trinh 2000). The rise of the cults in Europe and America has given birth to the anti-cult movement, the myths of "brainwashing", and other types of activities opposed to new religious movements (see Barker 1997). However, besides the public debates of new religions and openly hostile anti-cultism, there are numerous academic works attempting to create more or less comprehensive social theories of new religious movements (for detailed analysis 
and bibliography see Wilson 1990; Dawson 1998). Most often, sociological approach to the study of new religious movements proceeds from various theories of secularization, especially from that proposed by Peter Berger (Berger 1990). It is generally presumed that the processes of privatization and pluralism in modern Western society have determined the appearance of new religious marketplace where various confessions and denominations have to change and compete in order to satisfy the needs of secular and rational society. Some scholars insist that new religious movements represent the decline of traditional forms of religion in this new worldwide market. Other, following the theory of secularization formulated by Rodney Stark and William S. Bainbridge (Stark \& Bainbridge 1985), suppose that the rise of new religious movements is a sort of resistance to recent secularizing trends within traditional and conventional denominations and churches.

Proceeding from understanding of religion as essentially compensatory system, ${ }^{1}$ Stark and Bainbridge argue that secularization of the Western world in the 19th and 20th centuries is not a unique phenomenon, but a part of the universal process "occurring constantly in all religious economies" (Stark \& Bainbridge 1985: 429).

Properly understood, secularization refers to the periodic collapse of specific and dominant religious organizations as a consequence of becoming more worldly, more accommodating to the non-religious aspects of their cultural contexts. Contrary to Berger (and most other sociologists), in this more limited sense secularization should not be confused with the loss of the need for general supernatural compensators. The reverse is true. It is the failure to provide sufficiently vivid and consistently supernatural compensators that accounts for the decline of established religions. (Dawson 1998: 25).

This weakening of "established religions" or "conventional churches" leads to reaction against secularization, the latter being likely to take two primary forms: "revival" and "innovation". The first, viewed as "a response to early stages of weakness in the general compensators provided by conventional churches" (Stark \& Bainbridge 1985: 445 ) is resulted in sect formation. "In broad form, sects tend to be splinter groups from mainstream traditions that are seeking to revive what they think to be the original or pure spirit of the reli- 
gious tradition they are rebelling against" (Dawson 1998: 26). The second form leads to formation of cults which usually "do not have a prior tie with another established body in the society in question" (Stark \& Bainbridge 1985: 25). "Cults signify the introduction of a more unconventional mode of religious expression, one that tends to depart altogether from the dominant traditions of the churches that are being secularized" (Dawson 1998: 26). "Cult formation tends to erupt in later stages of church weakness, when large sectors of population have drifted away from all organizational ties to the prevailing faiths" (Stark \& Bainbridge 1985: 445). ${ }^{2}$

Obviously, these discussions are useful and productive for creating a general theory of new religious movements and of their social significance in contemporary world. However, the problem could be viewed not only in general but also in various contexts of national and historical peculiarities of different cultures. I would like to discuss such a peculiar situation in contemporary Russia - the country with national culture and religion being in a number of aspects not similar to those of Western (both Catholic and Protestant) civilizations. In fact, the forms of secularization that occurred in the West are not relevant to the Russian history of the 19th and 20th centuries. This particular case, in my opinion, demonstrates that the rise and functioning of new religious movements are often more complicated and probably depend not only on the secularization itself. In the following analysis, I will try to show that autochthonous Russian new religious movements, which had arisen in the early $1990 \mathrm{~s}$, and in a number of aspects were similar to their Western counterparts, should be interpreted as specific "crisis cults" responding to the collapse of the USSR.

It is well known that the majority of urban population of the Soviet Russia (I particularly mean the second half of the 20th century) was more or less "atheistic". Generally speaking, we can state that the Soviet ideology was successful in substitution for the Orthodox religious practice. It is obvious, in Peter Berger's terms, that the Soviet ideology (or more precisely the whole Soviet cultural practice) provided sufficiently significant symbolic universe to legitimize and maintain actual social reality. However, during the late Soviet decades (especially, the 1970s and the 1980s) there have risen a number of social and cultural movements not satisfied with the goals and 
rewards (both material and spiritual) offered by communism, "scientific atheism", etc. It would be interesting to discuss, in this connection, what religious and symbolic roots conditioned the political resistance of Soviet dissidents, alternative culture and arts, and the very ideology of intelligentsia, but just now I would like to discuss more or less literally religious tendencies in the late Soviet urban culture.

First of all, it is worth to mention various aspects of urban mythology having become widespread during the late 1970s and early 1980s. I mean beliefs and practices connected with ufology and extraterrestrial civilizations, extrasensory perception, alternative healing, paranormal phenomena, astrology, meditation, etc. Usually, those interested in such issues were educated technical specialists - so called tekhnicheskaia intelligentsia, being a large social class of the late Soviet urban population. These people (they often called themselves ischuschie - "seekers") constituted a number of spiritual circles or discussion clubs being widespread in big cities of European Russia, Siberia and the Ukraine. The circles collected and discussed various "paranormal evidences", practiced some spiritual exercises or extrasensory contacts and so on.

Another religious tendency of the late Soviet culture was represented by the so-called tserkovnye liudi (church people) - those oriented towards traditional Orthodox religion but not satisfied with the spiritual level of the official church. Some of them were oriented towards spiritual leaders or startsy (elders) who were members of the Russian Orthodoxy, some belonged to unofficial and underground Orthodox movements (the so called "catacomb churches"). The ideology and practices of these "church people" were usually determined by mystical spirituality and apocalyptic expectations and beliefs projected to contemporary social reality. The narratives by the church people, having been lately investigated by Russian folklorist Arina Tarabukina (see, for example, Tarabukina 1998; Tarabukina 1999), are abundant in stories about miraculous events, mystical revelations and the signs of the end of the world.

These two tendencies - new urban mythology and semi-Orthodox mysticism - seem in my opinion to be the basic ground for the emergence of autochthonous new religious movements in Russia in the 1990s. The collapse of the USSR and the Soviet ideology 
evidently resulted in symbolic vacuum, which was to be filled with some old or new social, political, religious and ideological patterns. For certain reasons the official Orthodox Church was not able to fill this religious market with its own symbolic products. Therefore, in large part, it was occupied by various foreign denominations and cults - from the Baptists and the Jehovah's Witnesses to the Unification Church and the Krishna Consciousness. However, there was still a place for authentic Russian religious movements having been born in the late 1980s or early 1990s. The most prominent of them were Yusmaliane (the White Brotherhood), Vissarionovtsy (the Last Testament Church), and the Bogorodichnyi Center (now called the Church of the Derzhavnaia Icon). The first of these had appeared to be the most radical and survived a serious crisis in 1993, when its members having expected the beginning of the end of the world took hold of the Sofia cathedral in Kiev. The leaders of the sect were imprisoned by Ukrainian authorities. Yet, the White Brotherhood continues to exist even now but it has transformed into less radical religious group and diminishes progressively. The other two movements are still populous and influential. It seems that both the Yusmaliane and the Vissarionovtsy were based upon the mentioned circles of the "seekers", and the Bogorodichnyi Center was especially influenced by "the church people" along with various followers of new Orthodox mysticism. Or, in terms of Stark and Bainbridge (see above), we can say that that the first two movements can be labeled as "cults", while the last - as a "sect".

From a scholarly point of view, "the problem of new religious movements" includes both sociological, religious, and ethnological aspects: usually, new churches establish specific types of social organizations, structures and systems of control, create original theological doctrines and ethic teachings, construct non-traditional rituals, possess their own religious writings and oral narratives. However, unlike sociologists, folklorists yet give very little attention to peculiar cultural practices of new religious movements and - on a broader scale - non-traditional religious movements of the nineteenth and twentieth century as a whole. The only exception is the Mormon movement (the Church of Latter-Day Saints) being discussed in numerous research works by American scholars (see Lee 1949; Fife \& Fife 1956). Discussion of popular culture and narrative repertoire of the Mormons has been even included in the famous 
monograph "American Folklore" by Richard Dorson (Dorson 1959: 112-121). A possible explanation is relative exoticism of the Mormons in the context of American religious cultures of the nineteenth and early twentieth century. It is also important that Mormon culture possesses a wide range of oral narratives comparable with various forms of "traditional" rural folklore (the legend of the Three Nephites, popular ballads, folk humor generally based on the theme of polygamy, etc.). The problem of new religious movements of the late twentieth and early twenty-first century is much more complicated from the folkloristic point of view. Complexity of contemporary means of communication leads to sufficient variety of cultural forms representing specifics of various new religious movements, and therefore "traditional" methods of folkloristic analysis could hardly be used here. However, I think that not only the culture of new religious movements should attract us folklorists, but the very contemporary methods of the study of folklore could contribute a lot to general understanding of nature, cultural roots and the future of new religious movements both in Russia and in the West. In this connection, I would like to discuss some results of ethnological fieldwork amongst the followers of the Last Testament Church (the Vissarionovtsy) in September 2001. First, I will describe the movement in general and then I will try to discuss some special features of its "unofficial" oral culture.

The sect of Vissarionovtsy (the official name adopted in 2000 is The Last Testament Church) has been founded by an amateur artist and former policeman Sergey Torop (born at Krasnodar in 1961) in Minusinsk (Krasnoiarskii krai, Southern Siberia) in 1991. He has taken a new name - Vissarion and identified himself as the Son of the Lord or the Word of the Lord. His followers venerate him as the Christ and consider his activities as the Second Coming. The first followers of Vissarion correspondingly considered themselves as the Apostles. In his early sermons, Vissarion even corrected the New Testament and told his audience about "the true story of the First Coming”. For example, his version of Judas' death sounds a little humorous, since it suggests a very Russian type of profound remorse (I will give the Russian text first below and then a possible English translation): 
Vposledstvii Iuda osoznal, kakuiu rokovuiu oshibku sotvoril. Velikaia tiazhest' legla na serdce ego. Izmuchivshis', on tri raza prihodil k kraiu propasti, no tak i ne reshilsia brosit'sia vniz. Posle sego on sil'no zapil. I odnazhdy v p'ianom ugare vozzval $\mathrm{k}$ Bogu i umer. Tak zavershilos' ego slepoe zhitie vo ploti. Afterwards, Judas realized what a fatal blunder he had committed. He became sick at heart. Having been worried to death, he approached the brink of a precipice three times but did not dare to fall down. After that he took to heavy drinking. And once having been drunk he invoked to the God and died. Thus his blind life in his flesh was finished. (Vstrechi, $21 ;^{3}$ quoted from Slovo Vissariona 1993: 210).

Both Vissarion himself and his first Apostles belonged to the abovementioned groups of "seekers" who were largely interested in various mystical teachings but were usually unaware of the details of the Russian Orthodoxy and the very Christian teaching. The majority of them had been brought up and educated in the Soviet "atheistic" spirit. Moreover, usually, they just did not possess any real knowledge of the New Testament, since an average urban family in the USSR did not have the Bible at home. Therefore, it might appear strange that they have chosen the Christian Advent as a basic pattern for their religious teaching and everyday behavior. However, I think that the explanation is simple. The fact is that the first wave of religious proselytizing in Russia during the late Perestroika years was represented by various Protestant and Evangelic preachers who popularized the New Testament either by sermons or by various screen versions of the Gospel. It seems that these films about the Christ and his disciples were especially influential upon those interested in spirituality and religious issues. I think that, to some extent, they prepared the pathway for the spread of both foreign and domestic sects and cults in post-Soviet Russia. As to the case of Vissarionovtsy, these preachers probably provided a symbolic pattern or a narrative plot for the very religious activity of the movement. It is worth to note that both Vissarion and his followers constructed their personal identities and images (including modes of behavior and speaking, clothes and so on) according to these cinematographic representations of the New Testament.

With the help of a small circle of his initial followers, Vissarion has begun to preach in Minusinsk, Krasnoiarsk and later in the biggest 
cities of the former USSR (Moscow, St.Petersburg, Kazan', Khar'kov, and others). The date of his first sermon was 18 August, 1991 and it has a special mythological meaning for the sectarians (as the day previous to the uprising (the so-called putsch) in Moscow). ${ }^{4}$ The primary audiences for his preaching were various clubs and groups of "seekers" interested in exotic and esoteric cults, "spirituality", non-traditional healing, astrology, meditation, etc. The main ideological point of Vissarion's sermons was the necessity to create a new human society free of violence and aggression, to live in harmony with physical environment. Later he and his followers created a complicated and synthetic dogmatic teaching. The ideas by Vissarion have latent but strong eschatological shade. He often stressed that his Coming is the last Coming, that his Testament is the Last Testament, and that the whole humankind is very close to the end of its history. However, he never predicted the exact time of the Judgment Day.

Soon after the beginning of "the Fulfillment", as the sectarians call the activities of their leader, in the early 1990s, Vissarion with his closest followers decided to found an isolated community in Western Saiany mountains - in the south-western part of Krasnoiarskii krai (Kuraginskii region). Here, on Sukhaia mountain, near Lake Tiberkul', they have began to build "the Solar City" (known also as "ecopolis Tiberkul", "the House of Dawn", "the Heavenly Settlement" or simply "the City"). The place is considered to be "the New Promised Land". Vissarion has even visited Jerusalem in order "to take the Promise from Palestine" and "to move it to the New Holy Land". Some of his disciples were to live with him in "the City", others - in the surrounding settlements of Kuraginskii region. Up to 1995 , the majority of the followers migrated to the Kuraginskii and the neighboring Karatuzskii regions.

Photo 1. Spiritual circle. Vissarionovtsy (followers of the Last Testament Church) in Krasnoiarskii krai. All photos by the author and Sergey Shtyrkov, 2001.

Photo 2. Funeral in Kuragino. Vissarionovtsy in Krasnoiarskii krai.

Photo 3. The House of Dawn. Ritual assent to the Holy Mountain. 
New Religious Movements and The Study of Folklore
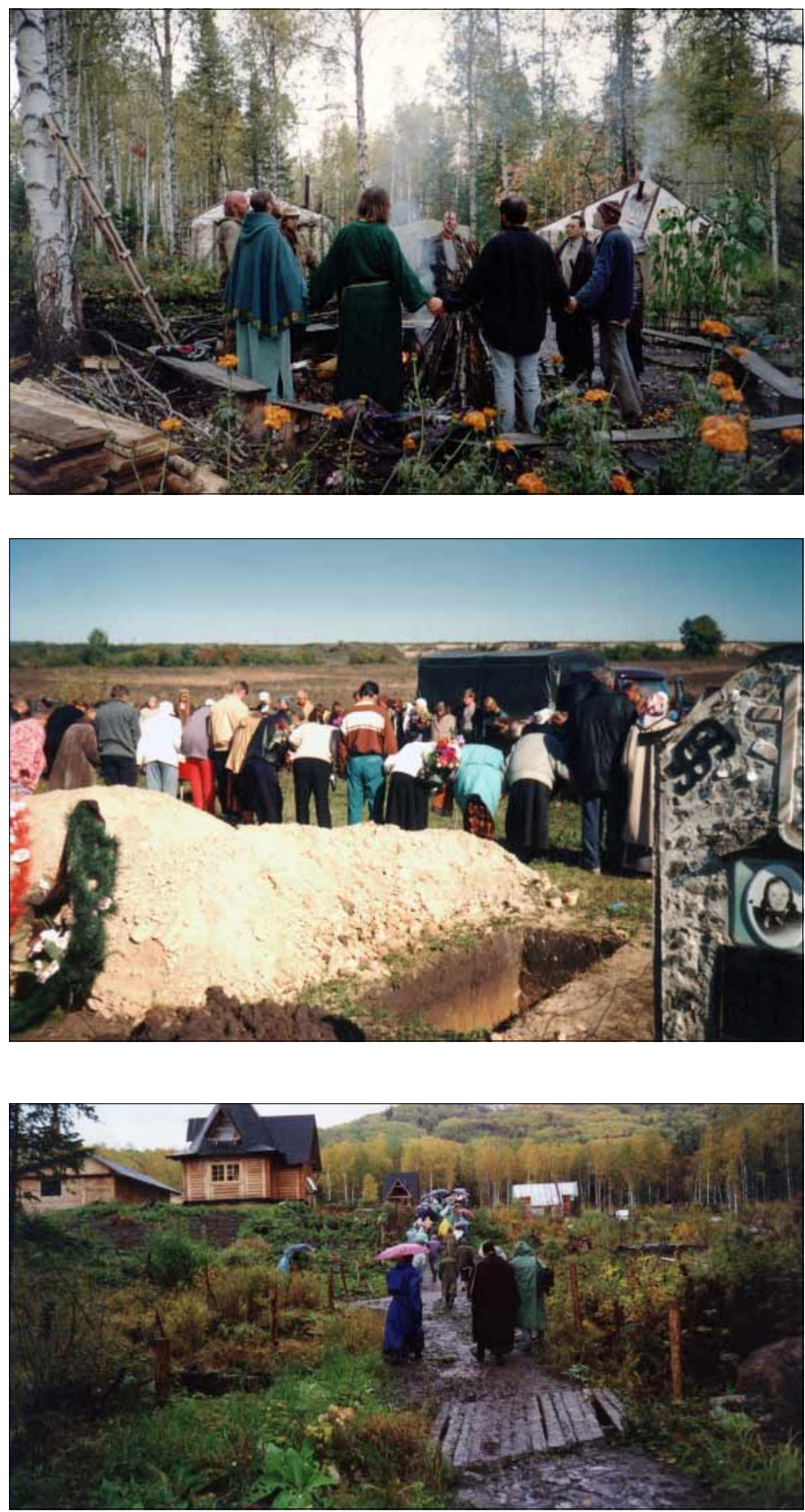

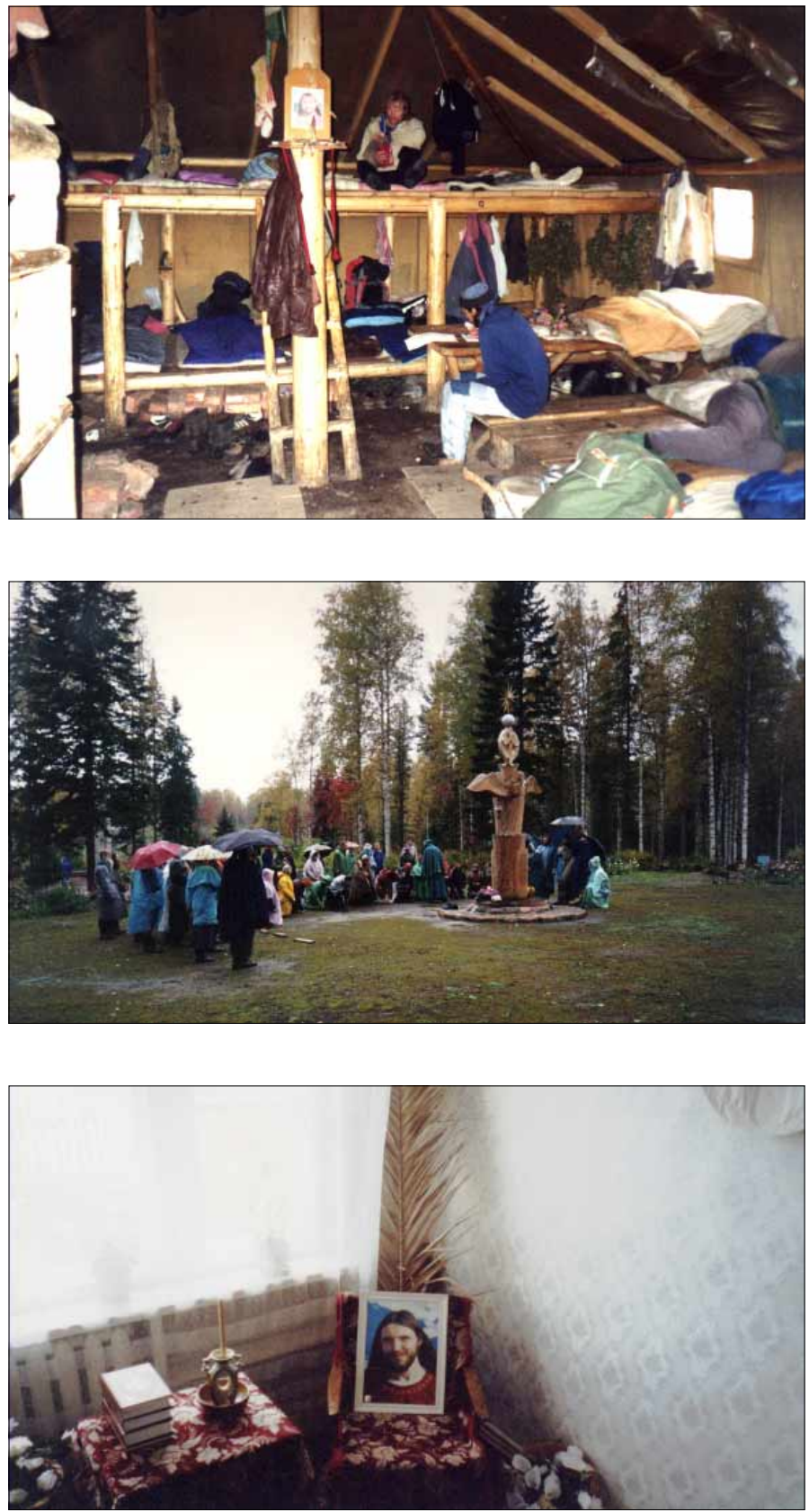
Today, the approximate number of Vissarion's followers in the Kuraginskii and Karatuzskii regions is about 5000. This territory has been generally divided by the sect's elite into three areas: (1) "the Mountain and the City", where Vissarion and about 60 of his followers live; (2) dereuni taezhnoi zony 'the villages of taiga zone' (Petropavlovka, Cheremshanka, Guliaevka, Zharovsk, in about 3545 kilometers from "the mountain"), where about 600 of the "followers" live; and (3) all the other settlements of the two regions including their centers - Kuragino and Karatuz. Those intending to settle in the taiga zone have to ask for Vissarion's permission. Those living in "the City" are strictly chosen by Vissarion. And Vissarion himself with his wife and children lives in a house built on the top of Mountain Sukhaia. The sect's elite also lives there: "the first disciple" and Vissarion's biographer Vadim Red'kin (who is creating the sect's Gospel called "The Last Testament"), the administrative leader of the sect (ustroitel' tserkvi) Stanislav Kazakov, and a small number of other disciples. "The City" is situated in taiga near the bottom of the mountain. Although today it consists of a dozen small wooden houses and a number of tents constructed in the wet and muddy taiga, the sectarians have created an ambitious plan of a future city with parks and palaces, schools and monuments, temples and churches.

The official social structure of the sect is comparatively simple. The head of the movement and the ultimate authority in all spheres of life is, of course, Vissarion. His ideas and instructions can be communicated directly to the "followers" during his "meetings with the believers" or indirectly - with the help of the sect's elite. The sectarians' ideology proclaims total equality within the sect: all except the Teacher are equal. However, the sect has a number of leaders who control various social and spiritual projects, economic activities, etc. Spiritual authority belongs to three priests, one living on "the Mountain", and the other two in the taiga zone. Each village of the zone has its own official starosta 'leader' who solves

Photo 4. The House of Dawn. In the pilgrims' camp.

Photo 5. The House of Dawn. Ceremony of ablution.

Photo 6. Informational Center in Kuragino. "The Teacher's Room": Portrait of Vissarion and the books of The Last Testament in a sacred corner. 
everyday problems of social and economic life. Some other settlements in the district have their own leaders too.

The theology and cosmology of Vissarionovtsy as described in their spiritual literature seem to be contradictory, too complicated, and hardly comprehensible for the majority of ordinary followers of Vissarion. However, there are some basic concepts playing decisive role for religious ideology and practice of the movement. These are: the idea of Vissarion's divine mission, the special cult of Mother Earth (or Mother Nature), and the concept of the so called "external consciousness" (or "galactic mind"), which means both extraterrestrial civilizations (either friendly or hostile to the humanity) and various personages of the world religions: the Blessed Virgin (usually called Mother Maria or Mother Mariam), St. Nicholas, Sergii Radonezhskii, Seraphim Sarovskii, Moses, Buddha and some others. The special cult of Mother Earth has no real relations to the peculiar veneration of Earth known in medieval Russian popular Christianity. Generally speaking, it is an ecological cult representing Mother Earth as a living person suffering from technological activities of the humanity, pollution of the environment, etc. The ideas of reincarnation and special energies connecting every person with the cosmic environment are very popular among Vissarion's followers. The teaching of the sect does not presume any personified evil. The Evil is considered to be "the negative energy" of mankind. All sectarians are complete vegetarians and oriented towards a set of additional prohibitions on "foods with negative energy" (tea, coffee, sugar, etc.). All forms of aggression are strictly forbidden because of their "negative energetic effect". There also exists a special mythology of individual "egoism" which is to be defeated by means of self-perfection.

The sect has no stable canons of spiritual services. Priests make their own decision concerning the particular structure of each new liturgy. However, all liturgies are constructed on the basis of various citations from the Orthodox liturgy. As to peculiar rituals of the sect, these are as follows: "spiritual circle" (presuming that people standing in a circle unite their personal energies), "merging with the Teacher's spirit" (each sectarian performs it every day at a conventional time), "merging with the Teacher" (presuming that Vissarion himself shares his energy with the followers), and "bless- 
ing of food". The sect has a number of "chapels", "temples" and "common houses" in various settlements. A complicated structure of "holy places" is being created on "the Mountain".

The sect has no initiation rituals and no rituals corresponding with the Christian baptism exist. The wedding ritual is performed during the liturgies. The funeral ritual is very peculiar since the beliefs of the movement presume reincarnation of human soul. During my field research, I observed a funeral ritual performed by a community of Vissarionovtsy located in the regional center Kuragino. Its participants brought the coffin with the dead to the cemetery singing spiritual songs. They put the coffin near the grave and made a "spiritual circle" around it. Then they sang both spiritual and secular songs. The main idea of the ritual was to perform "not a sad but joyful ceremony" since the reincarnation would bring new happier life to the soul of the dead sectarian. Singing and the whole atmosphere of the performance created certain ecstatic behavior: some of the participants began to dance. Some of them looked at the sky and said that they saw angels taking the soul from the dead body. The monument put on the grave was a big wooden cross of special form reproducing the main iconic symbol of the sect - a cross in a circle. Vissarion himself elaborated the symbol and some sectarians interpret it as symbolizing the unity of four religions: Christianity, Islam, Buddhism, and Taoism.

The sect has already created its own sacred calendar. It includes 3 major feasts: January 14 (Vissarion's birthday) which is considered to be "the true Christmas" and "the true New Year holiday", April 14 ("the Spring day"), and August 18 (the date of the first public preach by Vissarion - "the day of Fulfillment"). Vissarionovtsy have a new count of years beginning with the birth of Vissarion: year 2003 is, for instance, "the 43 year of the Epoch of Dawn". There are also a number of peculiar social and gender projects elaborated by the elite of the movement and being actively introduced into the everyday life of "the followers". Due to the peculiar ideology and eschatology of the sect, its members try "to go away" from traditional economic relations (including money or even natural change of the goods). The same is with the official medical care. Due to the special ideology of the struggle with egotism and the necessity to become a new purified people, the sect's communities use some 
special forms of social control within every sectarian group. The most exotic procedure of group control is called "the chair of wisdom" and presumes that once in a year each community member has to listen to suggestions and recommendations concerning his private and social life and behavior from his fellows.

However, the most interesting (and perhaps the most important) information on the Vissarionovtsy culture is presented by popular mythology or religious folklore of the members of the sect. I mean the everyday narratives which are produced by, that is to say, "common sectarian folk". These "belief narratives" are usually based upon urban mythology and urban legendary of the late Soviet period and the first years of post-Soviet era. The main aspects of the mythology are as follows: the notion of "bio-energies" influencing and determining the whole life of mankind; non-traditional healing beliefs; the idea of "extra-sensory" powers; stories about contacts with "extraterrestrial civilizations" and "the galactic consciousness"; eschatological beliefs. Some of my informants tried to construct a consistent cosmology based on these mythological issues. Some used traditional forms of urban legends in order to describe and illustrate their beliefs. Their narratives usually report "life accidents" supporting the ideas described above. The religious discourse of the sect does not include the concepts of sin and miracle in the Christian sense and therefore these concepts are substituted by quasiscientific explanations based upon the "extra-sensory theories". Since the sectarians completely reject official medical care and try to heal themselves by recalling and annihilating their negative emotions along with evil words and deeds (which are believed to cause negative energetic balance and consequently various diseases), their folklore is abundant in personal narratives or fabulates about successful healings of this kind. Another popular type of everyday narratives is about inevitable (and also caused by negative energy balance) punishment for evil or stupid thoughts or words about Vissarion and his teaching. Discussion and reporting of dreams has a special importance to Vissarionovtsy. They believe that during the first two weeks of January before their Teachers' birthday (these weeks are called vremia bezvremen'ia 'Time of No Time') they can dream omen dreams which should help them find the way of appropriate behavior and self-perfection. Finally, there exists a lot of stories about contacts with extraterrestrial civilizations and the information sent to 
the mankind via "contactors". Certain pieces of this information about the destiny of mankind and Vissarion's followers, about various moral and social problems emerging within the sect, are often published in the sect's newspaper and official web-site: http:// www.vissarion.ru .

It is well known that the major type of oral narrative in contemporary popular urban culture is represented by the so called "personal narrative". Western (and especially American) folklorists, unlike their East European colleagues, have been studying texts of this kind for about two last decades. In my opinion, the most detailed theoretical discussion of the study of personal narratives has been proposed by Sandra D. Stahl in her monograph published in 1989 (Stahl 1989). It seems that some aspects of personal narrative theory proposed by American scholars could be very useful for the study of the popular culture of Vissarionovtsy. The very definition of personal narrative suggests that the latter reports personal experience of a speaker. Whatever topic is discussed, the storyteller is always the main hero of the story. However, this feature is important not only in the sense of grammar. While reporting an accident, an individual positions himself toward both his immediate audience and more broad referential frames: the system of values, social hierarchy, and various cultural practices of a community. On the other hand, the act of personal narration presumes a sort of socialization of personal experience: not only is the latter being transformed into a plotline but also it is being positioned towards actual social reality. Finally, telling a personal story is not unidirectional communication: it presumes a complicated interaction of the teller's intentions and the audience's receptive acts. And this very peculiarity of personal narrative allows to consider the latter to be not simple reflections of personal and social values, "non-verbalized folklore", or "folk ideas" but one of the most important means of social construction of the whole human reality.

From this point of view, personal narratives by Vissarionovtsy seem to both represent and construct the basic social and cultural reality of the movement. Broadly speaking, these texts can be viewed as a "bricks" constituting the "meaningful reality" of the Last Testament Church. This hypothesis allows to make the cultural background of the movement more understandable. The majority of the elements 
of the "everyday mythology" characteristic of Vissarionovtsy inherit various legendary motifs and mystical practices widespread in the late Soviet urban culture. I think that, to some extent, these pieces of urban folklore functioned not only as means for constructing "the other world" but also as a sort of "urban paranoia", the latter having been a response for the evolution of industrial culture. It is natural to assume that actualization of such mythologies in the culture of Russian new religious movements was directly determined by the collapse of the late Soviet "symbolic universe".

Let us make some general conclusions. In my opinion, the sect of Vissarionovtsy or the Church of the Last Testament appears to be a typical "crisis cult" comparable to so-called "cargo-cults" and other messianic and prophetic movements of this kind. The main function of the cargo-cults is the adaptation of cardinal changes in social structure under the influence of an alien civilization having a technological character. Here a simple translation of meanings from the language of one culture to the language of another is not taking place, but principally new semantic constructions are being formed instead. And these constructions usually use various inversions or projections of traditional rituals, norms and customs of the native people. It seems that we observe the same situation in the case of Russian new religious movements having arisen at the moment of the collapse of the Soviet empire and ideology when many people have lost not only their social status and economic prosperity but the very meaningful world. One the one hand, there is a strong impact of Western economy, ideology, social patterns and even religious practices. On the other, there exist various urban beliefs, mythologies and paranoia which can be treated as traditional or native for the future sectarians. And the interaction of these two cultural factors results in the emergence of a peculiar messianic cult, which constructs a new meaningful and utopian world.

\section{Acknowledgements}

The research work was supported by The John D. and Catherine T. MacArtur Foundation. 


\section{Comments}

${ }^{1}$ In particular, they suggest to define religions "as human organizations primarily engaged in providing general compensators based on supernatural assumptions" (Stark \& Bainbridge 1985: 8).

${ }^{2}$ It should be noted that the typological distinction between sects and cults proposed by Stark and Bainbridge seems to be of special importance for the contemporary theory of religious organizations. It seems to be the only successful attempt to develop the dichotomy of churches and sects once drawn by Max Weber and elaborated by Ernst Troeltsch (see Troeltsch 1931). Usually, typologies and sub-typologies of religious sects or new religious movements proposed by 20th century sociologists of religion are based upon ideological or dogmatic premises and do not work from the anthropological point of view.

${ }^{3}$ Vstrechi ('Meetings') is one of the first books of "the Last Testament". It is based upon records of Vissarion's early sermons and meetings with his followers.

${ }^{4}$ The putch, which broke out on the 19th of August 1991, was the last attempt of the conservative communist elite to prevent the dissolution of the USSR and liberalization of political life in Russia. However, the effect was quite the contrary: on the 21st of August "the putschists" were arrested and the Communist party was banned. These August days of 1991 are usually considered to be the liberal revolution which in fact meant the end of the Soviet Union.

\section{References}

Barker, Eileen 1997. Novye religioznye dvizheniia. Prakticheskoe vvedenie. Sankt-Peterburg: Izdatel'stvo Russkogo Khristianskogo gumanitarnogo instituta.

Berger, Peter Ludwig 1990. The Sacred Canopy: Elements of a Sociological Theory of Religion. New York \& Toronto: Anchor.

Dawson, Lorne L. 1998. Comprehending Cults: The Sociology of New Religious Movements. Oxford: Oxford University Press.

Dorson, Richard M. 1959. American Folklore. Chicago \& London: University of Chicago.

Fife, Austin E. \& Fife, Alta S. 1956. Saints of Sage and Saddle. Folklore Among the Mormons. Bloomington: Indiana University Press.

Lee, Hector 1949. The Three Nephites: The Substance and Significance of the Legend in Folklore. Albuquerque: The University of New Mexico Press. 
Hall, John R. \& Schuyler, Philip D. \& Trinh, Sylvaine 2000. Apocalypse Observed: Religious Movements and Violence in North America, Europe and Japan. London \& New York: Routledge.

Slovo Vissariona, iavliaiushchego Poslednii Zavet ot poslavshego Ego Ottsa Nebesnego. Izdanie pervoe. Moskva, 1993.

Stahl, Sandra Dolby 1989. Literary Folkloristics and the Personal Narrative. Bloomington \& Indianapolis: Indiana University Press.

Stark, Rodney \& Bainbridge, William Sims 1985. The Future of Religion: Secularization, Revival and Cult Formation. Berkeley, Los Angeles \& London: University of California Press.

Tarabukina, Arina Valer'ievna 1998 Eshatologicheskie rasskazy "tserkovnykh liudei". Antropologiia religioznosti. Almanakh "Kanun." Vypusk 4. Sankt-Peterburg, pp. 397-454.

Tarabukina, Arina Valer'ievna 1999. Kategorii prostranstva i vremeni v mirovospriiatii sovremennykh "tserkovnykh liudei." Russkii fol'klor. Tom XXX. Sankt-Peterburg: Nauka, pp. 186-197.

Troeltsch, Ernest 1931. The Social Teaching of the Christian Churches. Vol. I. London: George Allen and Unwin.

Wilson, Bryan R. 1990. The Social Dimensions of Sectarianism: Sects and New Religious Movements in Contemporary Society. Oxford: Clarendon Press. 